DigitALCOMMONS @WAYNESTATE-
Michigan Journal of Counseling:

Research, Theory and Practice

Volume 35 | Issue 1

Article 2

$8-1-2008$

\title{
The Overlooked Group: Career Preparation for Counselors-in-Training
}

Devika Dibya Choudhuri

Eastern Michigan University

Irene Mass Ametrano

Eastern Michigan University, iametrano@emich.edu

Follow this and additional works at: https://digitalcommons.wayne.edu/mijoc

\section{Recommended Citation}

Choudhuri, D. D., \& Ametrano, I. M. (2008). The Overlooked Group: Career Preparation for Counselors-in-Training, Michigan Journal of Counseling, 35(1), 1-13. doi:10.22237/mijoc/1217548860

This Article is brought to you for free and open access by the Open Access Journals at DigitalCommons@WayneState. It has been accepted for inclusion in Michigan Journal of Counseling: Research, Theory and Practice by an authorized editor of DigitalCommons@WayneState. 


\section{The Overlooked Group: Career Preparation for Counselors-in-Training}

\section{Devika Dibya Choudhuri, Ph.D. and}

Irene Mass Ametrano, Ed.D.

Eastern Michigan University,

Ypsilanti, Michigan

Contact the authors at:

iametrano@emich.edu

There is a lack of specific resources for preparing counselors-in-training for their future profession. This article strives to identify and discuss some of the unique challenges and career preparation issues faced by master's level counselors. The responsibility of counselor education programs to send out new counselors who are adequately prepared for the workforce is addressed, and examples of career resources used in one master's level training program are provided.

Key Words: Career preparation, job finding challenges, counselor educator's responsibility, career resources $\perp \mathrm{n}$ its standards for the preparation of professional counselors, the Council for the Accreditation of Counseling and Related Educational Programs (CACREP, 2001) identifies career development as one of the core areas in which students should have knowledge and curricular experiences. CACREPaccredited counseling programs must offer coursework that covers areas such as career development theories and decision-making models, career counseling processes and techniques, and occupational and labor market information resources to name a few. Examples of assignments in these courses include inviting students to use their own lives as learning templates for career decision making; interviewing or shadowing professional counselors in their areas of specialization; or conducting mock interviews. However, much of the knowledge and preparation that students receive focuses on using the acquired skill and knowledge competencies with prospective clients (Brown, 2005; Pickman, 1997). Feedback from graduates of our own program indicates that students graduate as novice counselors, feeling vulnerable and unprepared for the career to which they have committed time, energy, and resources.

All kinds of professions, including music librarians (Elliot \& Blair, 2004), salespeople (Azar \& Foley, 2004), travel agents (Colbert, 2004), aviators (EchaoreMcDavid, 2005), police officers (Taylor, 2005), and chefs (Donovan, 2004), and of course, people entering business, have guides that prepare them to seek and land the perfect job. Most of these guides are marketed to counselors for use with their clients in these diverse fields. Even related human services fields, such as social work and psychology, have their career guides (Wittenberg, 2003; Sternberg, 1997). Amidst these riches, however, there appear to be very few resources available that focus on the career preparation of counselors (Baxter, 1994; Collison \& Garfield, 1996). Those that include counselors, such as Burger and Youkeles (2000), tend to focus on the earlier stages of choosing a career direction that is aligned with one's interests and aptitudes, rather than on later stages that involve preparation for entry into the field.

This paper strives to identify and discuss the unique challenges and career preparation issues faced by master's level counselors, and the responsibility of 
counselor education programs to send out new counselors who are adequately prepared for the workforce. Career resources used in one master's level training program are provided as examples of ways in which programs can respond to this need.

\section{Unique Career Issues for Counselors}

Counseling as a profession has historical roots in vocational guidance, but has evolved into an approach to helping people facing developmental and normative problems as well as psychopathology; it is often described as being indistinguishable from psychotherapy (Neukrug, 2000). The very breadth of settings and arenas in which counselors work, from schools and colleges, to public, private, and government agencies, to business and industry can be problematic for new counselors. Still far from firmly grounded, they must define a professional identity and advocate for themselves in fields and settings where they face much competition, and often little understanding, of professional counselors' preparation and skills. In a society where people can be called at home to be sold credit cards by persons labeling themselves "financial counselors", offered makeovers in department stores by "cosmetic counselors", or examined for inheritable diseases by "genetic counselors", new professional counselors face many challenges. Specifically, new counselors searching for jobs in schools, colleges and universities, and community agencies face slightly different challenges depending on their area of specialization.

In school counseling, increased threats of funding cuts on the Federal and State levels (Counseling Today, 2005) jeopardize the employability of school counselors. Between 2006 and 2016, employment for all counselors is expected to grow by $21 \%$, which is much faster than the average for all occupations (U.S. Department of Labor, 2008-2009). However, growth will vary by location and specialty area. Nationwide, educational, vocational, and school counseling is projected to grow by 13\% (U.S. Department of Labor), whereas in Michigan, growth is projected to be only $6 \%$ (Michigan Department of Labor \& Economic Growth, 2008).

In some states, such as Michigan, the legal change from requiring a teaching certificate for school counselor endorsement, to allowing non-teachercertified school counselors to obtain school counselor licensure, can be obstacle-ridden. Feedback from a variety of sources including students' shadowing/ interviewing assignments (see Appendix A), students seeking internships, intern supervisors, and recent graduates seeking employment, indicates that many school districts still give preference to teacher-certified counselors. School personnel are often unaware of the changes in the law and do not consider nonteacher-certified candidates, or simply do not want to place non-teacher certified counselors. Feedback from these sources also indicates that some school counseling functions are given to other professionals. At elementary school levels, more funding is available for school social workers than for school counselors; thus school social workers provide the services that school counselors could provide. In high schools where social workers, psychologists and counselors are employed, counselors may be assigned the scheduling and guidance functions, while the social workers and psychologists conduct assessments and do the more "psychotherapeutic" counseling functions. This is not consistent with the professional school counselor's role as defined in the Michigan Comprehensive Guidance and Counseling Program (2005).

Over the last ten years, anecdotal feedback from program graduates seeking employment as counselors in higher education settings, indicates that they may be at a disadvantage. Advertisements for positions in college and university counseling centers often require degrees and licensure as psychologists and social workers, even though these professionals have less training and preparation than counselors in the unique developmental and life issues that college students face. Graduates have found that the directors of such centers, who develop position postings and requirements, are themselves often psychologists or social workers and are therefore unacquainted with the current training and preparation of college counselors. They frequently assume that counselors are less clinically skilled, and psychologists often view diagnosis as their purview alone. Yet most counselor licensure laws, including Michigan's law, includes diagnosis in the counselor's scope of practice (ACA, 2008; Schaeffer \& Ametrano, 2006)

Equally, if not more challenging, are the issues faced by community and mental health counselors. There is a great deal of overlap among the counseling-related services provided by various mentalhealth professionals, with individuals from different professions often being hired to perform the same tasks (Altekruse, Harris, 
\& Brandt, 2001). While the scope of practice for licensed professional counselors in most states includes assessment, diagnosis, treatment planning, as well as counseling and psychotherapy (ACA, 2008), feedback from students, prospective intern supervisors, and graduates seeking employment, indicates that agencies often view master's level social workers as more employable than counselors. With the exception of rehabilitation counseling, where counseling training is typically required, many position postings ask specifically for MSW candidates, while listing a set of job functions that master's level counselors are trained to perform competently. However, most mental health administrators appear to have social work backgrounds and thus tend to hire primarily social workers (Altekruse, Harris, \& Brandt). Michigan occupational projections for the years 2004 to 2014 reflect twice as many positions for mental health and substance abuse social workers as for mental health counselors. Positions for mental health counselors are projected to increase by $11 \%$, from 2040 to 2280, whereas positions for mental health and substance abuse social workers are projected to increase by $15 \%$, from 4220 to 4870 positions. Positions for rehabilitation counselors are projected to increase only 7\%, from 1910 to 2050 (Michigan Department of Labor \& Economic Growth, 2008)

Despite these trends and hiring practices, it has been the authors' experience that agencies in which counseling interns are placed often praise their skill level and therapeutic readiness as being superior to that of the social work students they supervise. The graduate preparation model whereby social work students are given field placements beginning at the time of entry into the program is very different from the preparation model for counselors, where practicum and internships in the field are culminating experiences that follow the acquisition of knowledge and skills, rather than accompany them. Thus, while social work students in a field placement may be at any point in their programs, counseling interns will be at the terminus of theirs.

All of these challenges mean that in the job search process itself, counseling applicants will need to be ready and prepared to be strong advocates for the profession and themselves. Rather than being discouraged by what appear to be few positions, they must prepare themselves to seek out and compete effectively with other mental health and social service providers. To empower students to do this, counselor educators must prepare them systematically during the master's program. The tools these students need include a thorough understanding of the requirements for professional counselorlicensurein theirstate,

along with an understanding of the scope of practice of such licensure, a sense of worth and appreciation for the knowledge and skills they are learning, the confidence to present themselves as competent, and practice in advocating for the profession and themselves. As Altekruse, Harris, and Brandt (2001) noted, in order to compete with other mental health professionals, professional counselors need to be able to communicate their role to legislators and to the public, and they need to demonstrate that they have something important to offer. 


\section{Preparing Competitive New Counselors: Training Aspects}

In counselor preparation programs, there is often a course early on that introduces students to the profession, addressing the curricular requirements of the CACREP standard known as Professional Identity (CACREP, 2001). Similarly, students in specific specialization tracks (i.e. school, college, community), take courses that address professional and ethical issues in the particular field they are entering. Such courses, along with career development courses, are wonderful opportunities to provide specific and developmentally appropriate groundwork and training for the counselor's own career preparation. For instance, in an early course, students are assigned a shadowing and interview project where they follow and talk in depth with a counselor in the field that they seek to enter (see Appendix A). This assignment helps students to build a real world understanding of the parameters of such positions, as well as exposing students to the important process of networking. Later in their programs, students are offered experiences in which they practice job search skills, including interviewing (see Appendix B).

In addition, it may be helpful to schedule workshops and professional development opportunities to cover special topics. The career skills that counseling students need to know and apply to themselves include building an appropriate resume or vita, writing persuasive and self-advocating cover letters, understanding the job search process in their specific fields, and preparing themselves for job interviews and follow up. Each of these topics needs to be focused and developed specifically for counselors, rather than using a onesize-fits-all generic career counseling model. In the following sections, some of these special issues are discussed.

\section{Developing an Appropriate Resume or Vitae}

The usual model of a business-type resume does not work adequately for would-be counselors since the one-page, terse summary format tends not to capture successfully the professional counselor's skills and experiences. Students are often unaware of other options; for example, increasing the resume format to multiple pages, or changing the typical chronological format to a functional one where skills and areas of expertise acquired from different places and times are categorized. Another option is to use a curriculum vitae (C.V.) rather than a resume. Where the resume is a brief, persuasive document intended to evoke interest and action and is focused on a specific position (Connelly, 2007, May), a C.V. is a more detailed summary of one's qualifications and work experience.

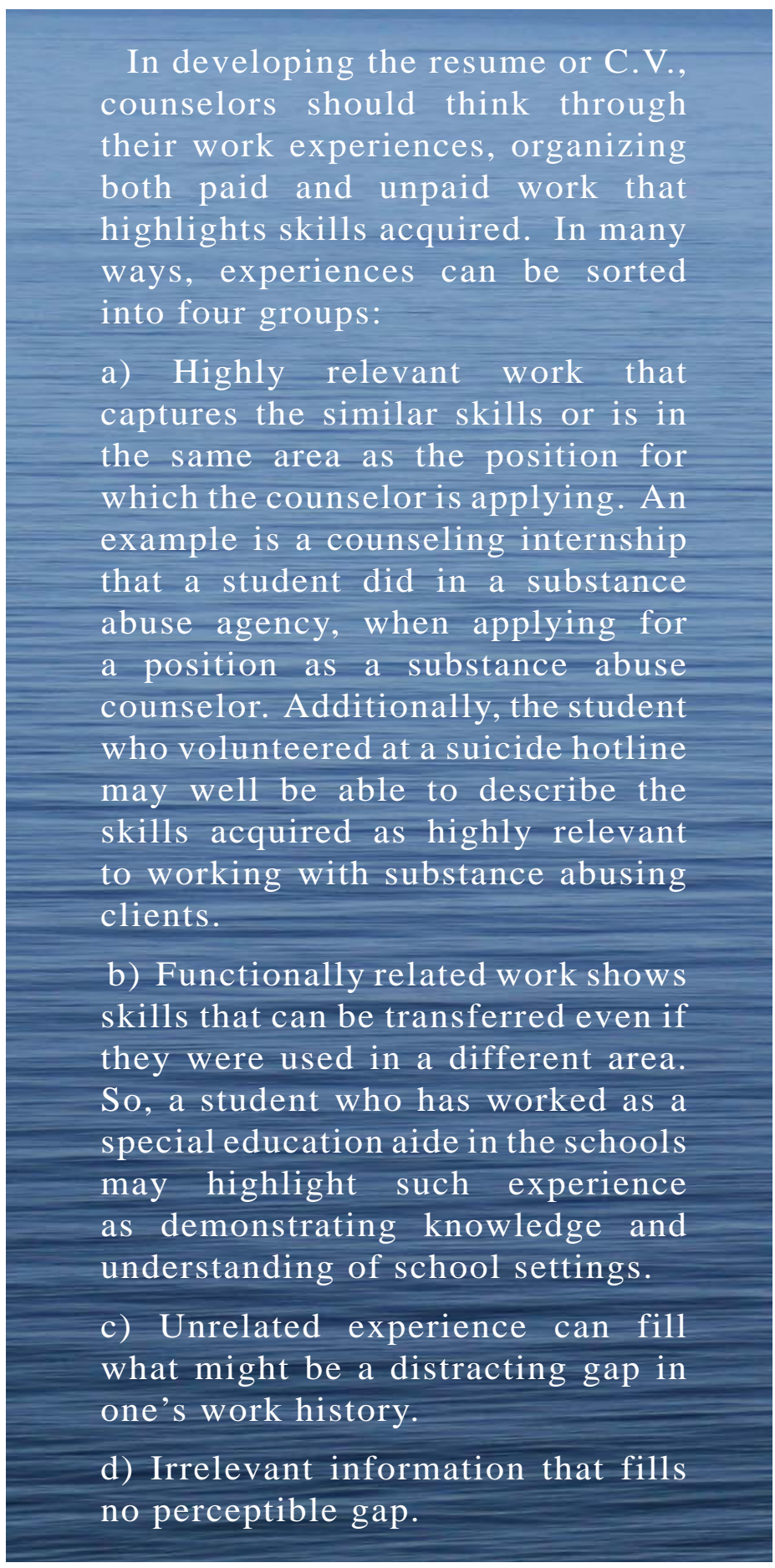

The student's task is to describe the first group in detail, highlight the main points of the second group, mention the third group perfunctorily under "Other Experience” and not include the irrelevant information from the last group. For most people, a chronological ordering works well for the information in groups one and two. However, because of the process of going through a graduate program, students sometimes find 
that their most relevant experience is not the most recent. In that case, they should consider using a functional format, with a heading such as "Related Experience" and describe the most relevant clustering of experiences regardless of chronological continuity (see Appendix C).

Another point in developing counseling resumes is the need to add sections that may not fit in a traditional format. For instance, professional associations and memberships demonstrate professional commitment; honors and awards showcase ways in which the candidate performed in a stellar capacity; while detailing multilingual capacities is often a great asset given the need to be prepared in working with diverse populations.

\section{Networking}

Again, new counselors may often overlook critical aspects of this process when using a one-size-fits-all approach. The value of networking cannotbeoverlooked, and many employed counselors have mentioned to us that they obtained their first entry through talking to a network regarding job contacts and vacancies. This includes asking teachers, counselors, and administrators where one has interned, volunteered, or worked, about job openings, as well as audaciously using friends, relatives, and community members if they can refer to contacts with hiring power or have information about local counselor vacancies. Joining national and local professional associations to develop a professional support network and obtaining current employment information through journals and newsletters may be an underutilized strategy. In a tongue-in-cheek column, Connelly (2007) identifies job search mistakes made by counselors, including relying solely on the internet, assuming that all jobs are advertised and not using networking.

\section{Advocacy}

Students must be well trained in writing and developing persuasive cover letters that encourage employers to consider them as viable applicants. As discussed previously, counselors have to struggle with misperceptions about their training, clinical skills, and professional licensure. Understanding the profession's scope of practice, which is defined in each state's licensing law, is essential so that counselors neither practice outside of their scope nor allow it to be limited by others (Schaeffer \& Ametrano, 2006). In looking for jobs, counselors must be knowledgeable enough to educate potential employers about their scope of practice so that these employers do not unknowingly limit the counselor's scope. A useful assignment for students in courses in the latter part of their programs is to develop sample cover letters in which they advocate for themselves by describing national certification and state-specific professional licensure requirements, restrictions and scope of practice (see Appendix D).

Counselor educators bear a great deal of responsibility at this step. Along with counselors themselves, counselor educators must advocate for professional counselors' rights to practice their profession fully. It is essential that in preparing counselors, educators remain aware of the current job landscape and day-to-day realities for counselors in the specialization tracks. To maintain this awareness, it is necessary to develop close and continuing relationships with professionals in the field: the agencies, districts, and organizations that hire the counselors one trains. These contacts allow counselor educators to insure that such professionals are informed about the preparation of counselors. In essence, the approachability, knowledge, and preparation of the counselor educator are crucial components in being ambassadors for the profession and for the students. If counselor educators are known and respected, then a student who brings a degree and a reference from the program is correspondingly valued. Alumnae of the program should be cultivated and ongoing connections maintained because they too serve as excellent and knowledgeable references for the training standards of the program. One way the counseling program can maintain these contacts is by developing and sustaining a board or committee of advisors, drawn from the field, who are professionally committed, interested, and also representative of the places that might hire counselors. An important activity that can be undertaken by the program and/or its advisory board is to conduct periodic structured assessments to get an accurate picture of the job market for counselors in the region.

\section{The Interview Process in Counseling}

Once students have a foot in the door, so to speak, by having obtained an interview, it is helpful if they have rehearsed responses and are knowledgeable about protocols for interviews in the settings in which they seek employment. Beyond generic questions about one's strengths and interests in the position, counselor applicants may well be asked more detailed questions. Feedback from graduates who have obtained positions and from students preparing mock interviews in an

Michigan Journal of Counseling • 35:1 • August 2008 
advanced course (see Appendix B) indicates that candidates are frequently asked to apply their knowledge to specific situations that may arise on the job. In community and mental health interviews, counselors may be asked to give specific examples about their experiences and approach to issues such as diagnostic dilemmas, crisis situations, clinical supervision, psychosocial assessments, professional boundaries, ethical dilemmas, and managed care. In school counseling, applicants may be asked about the state specific comprehensive guidance and counseling plan, dealing with school violence and crisis, illegal substance use, child abuse or suicide, or their approach on how to enhance parent participation. College counseling applicants may be asked about favored theories of student development, experience and knowledge in crisis intervention, availability and readiness to take psychoeducational programs into residence halls, serve in on-call functions during weekends, liaison with other student affairs units, as well as specific clinical knowledge and experience with common campus issues such as dysfunctional relationships, eating disorders, depression, or substance abuse.

In addition, students must learn to apply the general skills they have learned to use with clients to good use in managing and negotiating a cordial atmosphere during the interview. If students spend time learning how to develop rapport in counseling skills courses, there is no reason not to use this learning during the interview. However, there are several reasons why students need to be encouraged and trained to do this. Often, students, like any other new entrants into a professional field, feel like supplicants in the process, unable to exert any degree of power or control over the process. With expectations about the expertise of their potential employers, they may feel that using rapportbuilding skills during the interview will be obvious and manipulative. The uncertainty that accompanies any new endeavor also brings shades of the imposter syndrome (Furnhum, 2002), where applicants begin to doubt that they have any special competence and are certain that their glaring inability to perform will be instantly recognized. Finally, sometimes students simply do not see the potential for application of their skills outside counselor-client relationships.

Specifically, students can use their acquired skills to turn interviews into productive conversations and prevent them from turning into interrogations (see Appendix E).

\section{Conclusion}

It is ironic that the very professionals who are trained to assist persons with career needs are often the least prepared for their own career searches. As counselor educators and professional counselors, we owe it to our profession and to our students to prepare them more effectively to advocate for themselves and find success in the job-search.

Our efforts will benefit students who will be more successful in their job searches, resulting in more satisfied and positive alumnae. The training program placement rates will increase which will also enhance the popularity and viability of professional preparation programs in counseling. The more professional counselors there are working in the field, the better for the reputation, visibility, and growth of the counseling profession. Ultimately, better career preparation and success will serve the public who will access practitioners who enjoy what they do and who provide responsible, professional services. 


\section{References}

Altekruse, M. K., Harris, H., \& Brandt, M. (2001). The role of the counselor in the 21st century. Denver, CO: Love Publishing.

American Counseling Association. (2008). Licensure requirements for professional counselors: A state by state report. Alexandria, VA: Author.

Azar, B. \& Foley, L. (2004). Your successful sales career. New York: American Management Association.

Baxter, N. (1994). Opportunities in counseling and development careers. Lincolnwood, IL: VGM Career Books.

Brown, D. (2005). Designing and leading comprehensive school counseling programs: Promoting student competence and meeting student needs. Belmont, CA: Thomson Brooks/Cole.

Burger, W. R. \& Youkeles, M. (2000). The helping professions: A career sourcebook. Belmont, CA: Brooks/ Cole.

CACREP (2001). 2001 Standards. [Available at http://www.cacrep.org/2001Standards.html. Retrieved April 5, 2005].

Colbert, J. (2004). Career opportunities in the travel industry. New York: Checkmark Books.

Collison, B. B., \& Garfield, N. J. (Eds.).(1996). Careers in counseling and human services. Washington, D.C.:

Taylor \& Francis.

Connelly, A. R. (2007, May). The career marketing toolkit. Counseling Today, p. 30 Connelly, A.R. (2007, December). How NOT to find a job. Counseling Today p.29.

Donovan, M. D. (2004). Opportunities in culinary careers. Chicago: VGM Career Books.

Echaore-McDavid, S. (2005). Career opportunities in aviation and the aerospace industry. New York: Checkmark-Ferguson.

Elliot, P. \& Blair, L. (Eds.) (2004). Careers in music librarianship II: Traditions and transitions. Lanham, MD: Scarecrow Press.

Furnham, A. (2002). The imposter syndrome: getting in touch with success. In E. Biech (Ed.) The 2002 annual: Volume 1, training (pp. 10-18), San Francisc: Jossey-Bass/Pfeiffer.

Michigan Department of Labor \& Economic Growth: Bureau of Labor Market Information \& Strategic Initiatives. Michigan employment projections. Retrieved January 25, 2008 from http://www.milmi.org/cgi/dataanalysis/AreaSelection. asp?tableName=Occprj.

Michigan School Counselor Association. (2005). The Michigan comprehensive guidance and counseling program. Grand Rapids, MI: Author.

Neukrug, E. (2000). The world of the counselor: An introduction to the counseling profession. Pacific Grove, CA: Brooks/Cole.

Pickman, A. J. (Ed.) (1997). Special challenges in career management: Counselor perspectives. Mahwah, N.J.: Lawrence Erlbaum Associates.

Schaeffer, S. S., \& Ametrano, I. M. (2006). Counselor licensure and scope of practice in Michigan: Historical perspectives and current practice. Ann Arbor, MI: Dollarbill Copying.

Sternberg, R. J. (Ed.) (1997). Career paths in psychology: Where your degree can take you.

Taylor, D. L. (2005). Jump starting your career: An internship guide for criminal justice (2nd Ed.). Upper Saddle River, NJ: Pearson Prentice Hall.

U. S. Department of Labor. Occupational Outlook Handbook (2008 - 2009). Washington, DC: U. S. Government Printing Office.

Wittenberg, R. (2003). Opportunities in social work careers. Chicago: VGM Career Books. 


\section{Appendix A}

Shadowing and Interviewing Assignment

Description:

This assignment is given in an introductory counseling class, which is taken by graduate students who are newly enrolled in the Counseling program or are considering applying to the program. Students are expected to read an overview of the field (Neukrug, 2000) from their textbook as well as an article from a journal in their field such as The School Counselor or Journal of Mental Health Counseling, prior to their field experience. The course instructor often assists students in finding appropriate professionals, though it is the student's responsibility to make contact and set up the shadowing and interview. Students are told that they may not shadow and be present for confidential counseling sessions, but will still get a sense of the daily work life.

Instructions to students:

The purpose of this assignment is to increase your knowledge of the actual professional experience of the career to which you are aspiring. For this project, you will make contact with a professional counselor in the area of your choice (examples include a middle school counselor, a career counselor, a mental health counselor in an agency, or a substance abuse counselor) and set up the opportunity to shadow them as much as possible through a minimum of six hours in a typical working day (the hours do not have to be in a single block though that may well be helpful to your understanding of the pace). You will also interview the professional about their career, their educational background, their responsibilities, successes, frustrations, schedules, etc. In class, we will be discussing your experiences and findings in small groups, organized by setting. You will then write up your experiences and the data from the interview, incorporating the relevant text readings, in a reflective paper of 7-8 pages.

Pedagogical outcomes:

While students enter the program having chosen a specialization area (such as school or community counseling), this assignment often validates their career choices. Sometimes, this assignment allows students to explore an unconsidered aspect of their chosen field. For instance, school counseling students who choose to shadow and interview a counselor working in elementary school settings are often very surprised and impressed by the level, quality and engagement of counseling that occurs. On the other hand, community counseling students get a sense of the breadth of their field as they notice the vast number of mental health providers from different disciplines. 


\section{Appendix B}

\section{Mock Interview Assignment}

\section{Description:}

This assignment is given in an advanced community counseling course that addresses ethical and professional issues. The assignment provides opportunities for students to observe their peers in mock interviews, provide feedback, and discuss the interviews with classmates and the course instructor.

Instructions to students:

Each student will select an ad (or a composite of several ads) for a counseling job in an agency setting. Note that this must be a community agency and not a school or college/university. The job must require a master's degree in counseling or a related mental health profession (social work, psychology), along with the appropriate state licensure/certification.

The student will "apply" for the selected position and submit an application that includes the following:

1) Professional resume

2) A letter of interest/introduction that describes:

- your master's degree program: “core” areas your training covers; specialty courses/areas of interest to you

- your internship requirement and setting (use a hypothetical setting if you have not begun your internship)

- how your degree compares with degrees in other mental health professions (social work and psychology)

- your counseling license; a counselor's scope of practice

In dyads, students will develop a 15 - 20 minute roleplay of a job interview. The interview should be based on one of the positions for which a student developed an application. Students will work together to develop the interviewer's questions and the interviewee’s responses. "Mock interviews” will be presented to the class.

Pedagogical outcomes:

Students find this process useful in their preparation for job interviews. They learn new approaches by watching other students go through an interview process. In addition, they are often surprised to hear about things that they did well, and they welcome suggestions about things they could have handled more effectively. They leave the class feeling a bit more confident about applying for jobs.

\section{Modifications:}

- A useful feature to add would be to videotape each interview. Students would then be able to see themselves, and the feedback from peers would be more meaningful.

- Professionals from the field could be brought in to conduct "mock interviews." This experience would provide a more realistic feel for actual job interviews. 


\section{Appendix C}

\section{Handout on Developing a Resume that Highlights Counseling Skills}

Job seekers entering or leaving the human services fields often feel they must use chronological formats to describe their job responsibilities. Yet, using such strategies does not strengthen their resumes.

\section{Example:}

While completing her Counseling degree, Carla served as an intern with a mental health counseling agency. She had also been a volunteer with Big Sisters and helped to manage their new member recruitment campaign. Prior to that, she managed an office.

Take a look at her "before” resume and see how well it markets her for a Counseling position

\begin{tabular}{l}
\hline EXPERIENCE: \\
Intern Counselor, Mental Health Counseling, Inc. 1996 - Present \\
Served as counselor intern, counseling teenagers, completing case files and consulting with Senior \\
Counselor to review and approve counseling strategies. \\
Volunteer, Big Sisters 1992 - 1995 \\
Worked on the member recruitment campaign which involved interviewing and assessing new \\
volunteers for acceptance into program. \\
Office Manager, Frampton Construction 1988 - 1992 \\
Managed office functions including bookkeeping and reception for a small construction firm.
\end{tabular}

Now take a look at changing the format to skill headings and content. Notice how this new resume information presents her as being much better qualified. Of these two examples who would you call to interview for a counseling position?

\begin{tabular}{l}
\hline Counseling / Case Management, Mental Health Counseling 1995 - Present \\
Client Needs Assessment \\
Family Systems Counseling \\
Case Documentation and Reporting \\
Client Education \& High Risk Prevention Counseling \\
Mentor Assessment \& Program Placement, Big Sisters 1992 - 1995 \\
Interviewing and Placement of Volunteer Mentors \\
Program Coordination / New Recruit Orientation \\
Administrative Management, Frampton Construction 1988 - 1992 \\
Office Systems Administration \\
Staff Training and Supervision \\
\hline
\end{tabular}

You can also use numbers to describe your responsibilities. Notice in the following example that quantifying paints a much broader image of Carla's skills and capabilities than a pedestrian list of responsibilities:

Managed a case load of 25 adolescents from culturally diverse, socioeconomic levels, many of whom were at high risk for delinquency, teen pregnancy and drug usage. 


\section{Appendix D}

\section{Sample Cover Letter Advocating for Community Counselors}

Date

Prospective Employer

Organization/Agency

Address

City, State, Zip

Dear Ms./Mr./Dr...

I am responding to your advertised position in the Site of ad (month day, year) for a psychotherapist/counselor/ mental health worker in organization/agency name. I hold a master's degree in community counseling from University and am a limited licensed professional counselor (LLPC) in the State of Michigan. The scope of practice for licensed professional counselors includes testing and assessment, diagnosis and treatment planning, along with other counseling-related activities. Thus as an LLPC, I can perform all the activities that are customarily given to other master's level mental health professionals.

In addition to assessment, diagnosis, and treatment planning, my training in community counseling has equipped me with the knowledge and skills to establish and maintain therapeutic relationships with individuals, groups, couples, and families. Beyond my basic counseling curriculum, I also took specialized coursework in substance abuse, crisis intervention and community resources and advocacy.

The 600-hour internship, which is the required capstone experience for my CACREP accredited program, was in setting(s). There I performed intake interviews, prepared documentation for managed care reimbursement, and assessed clients for treatment eligibility. I also maintained a caseload of clients presenting with substance-related and other DSMIV disorders, including co-occurring diagnoses. I worked with individuals, groups and families, focusing on the development of life skills, self-reliance, recovery, parenting, and healthy relationships.

Your organization, organization/agency name, has an outstanding reputation for providing services for kind of population, a population I am committed to working with. I believe this is an environment that aligns perfectly with my long-term career goals. Enclosed you will find my resume for your review. I look forward to speaking with you in the near future.

Sincerely

\section{Your Name}

\section{Address}

City, State Zip

emailname@server.net

Phone: 555-555-5555 


\section{Appendix $\mathrm{E}$}

\section{Handout: Using Counseling Skills in the Job Interview}

\section{INTRODUCTION}

You walk into a small room with a stranger who may be anxious or nervous, and you begin to employ verbal and nonverbal strategies and techniques to develop a relationship. Perhaps you give a choice about seating, make a humorous remark to put the person at ease, ask some open ended question that allows the other person to decide where to begin the conversation, use appreciative and sincere facial expressions, manage your body language to express interest in what they are saying without encroaching into their space.

This is the nuts and bolts of counseling skills and by this time in your graduate training program, you have learned to do this with clients. There is no reason not to apply the above scenario to a job interview where you are the candidate!

I'm nervous!

So what? There have been plenty of times where you were nervous with a client and you managed.

I'm the one being assessed here!

Yes, and clients have been assessing you for your suitability to be their counselor and you have coped.

This isn't a client I'm talking to--it's other mental health professionals--They will see right through me!

Good interpersonal skills, used appropriately, are not a scam. They are a means of expressing your interest and appreciation and holding up your share of the conversation. Everyone likes not to have to do all the work. If your interviewers walk away having enjoyed talking with you, isn't that better than having it be more painful? 


\section{STAGES IN THE JOB INTERVIEW AND APPLICATION OF ACQUIRED SKILLS}

\begin{tabular}{|c|c|}
\hline Walking into the room & $\begin{array}{l}\text { If it is a one-on-one interview, what are the barriers between you and the interviewer? Strategize } \\
\text { how you can get around the physical limitations of the space and seating. You may even break } \\
\text { the ice by asking about the space and its usual usage. }\end{array}$ \\
\hline $\begin{array}{l}\text { Beginning the } \\
\text { interview }\end{array}$ & $\begin{array}{l}\text { Just as you would with a client, assess the tone of the first questions. Are the questions fact- } \\
\text { focused, businesslike, or do they invite self-disclosure by offering some about the interviewer or } \\
\text { the organization? As you address some of the general questions regarding yourself, produce a } \\
\text { statement that is both personable yet appropriate. You have done this before in preparing a pro- } \\
\text { fessional disclosure statement for your clients--do it for potential employers in verbal format. }\end{array}$ \\
\hline $\begin{array}{l}\text { Conversation - } \\
\text { NOT Interrogation }\end{array}$ & $\begin{array}{l}\text { If you allow an exclusive and one-way question and answer format, where you answer the ques- } \\
\text { tion and wait expectantly for the next, you have a hand in turning the interview into an interro- } \\
\text { gation. Don't dilute the focus of the interview, but feel free to ask pertinent questions or make } \\
\text { comments in the course of the interview. A particularly adept way of doing this is to attach it on } \\
\text { to your response to their question. For instance, if you have been asked about your experience } \\
\text { with crisis intervention, you may give your response and then ask if the organization follows a } \\
\text { particular protocol through experiences they have had. You want to demonstrate respect for the } \\
\text { interview process and show that you take it seriously, so you will want to be appropriately formal } \\
\text { in your responses. Just as with clients, however, you would assess appropriateness by the cues } \\
\text { you are given in the language and formality of your interviewers. Similar to clients, you will } \\
\text { want to match and pace them, while maintaining a formal tone that is a step beyond that of your } \\
\text { interviewers. For instance, if they use descriptive curse words during the interview, that does not } \\
\text { give you license to do the same, but it does mean that you can be more informal in your descrip- } \\
\text { tions.Just as in counseling, you wish the client to recognize that this is a professional relationship } \\
\text { but also feel comfortable with you, in a job interview you want your interviewers to both appreci- } \\
\text { ate and recognize that you are serious about your interest in the position, but also imagine you as } \\
\text { a potential colleague and co-worker. }\end{array}$ \\
\hline $\begin{array}{l}\text { Responding to } \\
\text { questions }\end{array}$ & $\begin{array}{l}\text { Most of the questions you will be asked will not relate directly to the information you learned in } \\
\text { classes. There are ways, however, to show how your skills and background meet the employer's } \\
\text { needs using the information you gained there. As you would with a client, know as much as you } \\
\text { can about the employer organization and tactfully "weave" your knowledge into the interview. } \\
\text { Simply spouting facts or statistics--or prefacing a question with a lot of memorized information- } \\
\text {-is not the answer. Showing you have "done your homework" demonstrates both your interest in } \\
\text { the position and your commitment and thoroughness so it's important for you to secure informa- } \\
\text { tion on an employer before you interview. }\end{array}$ \\
\hline $\begin{array}{l}\text { The "strengths and } \\
\text { weaknesses" question }\end{array}$ & $\begin{array}{l}\text { Applicants have often generically been told to find ways to "play" this question; conventional } \\
\text { advice recommends candidates highlight a weakness like "I'm a perfectionist" and turn it into a } \\
\text { positive. However, in this context do not do this. Describe a skill or personality aspect that you } \\
\text { wish to improve upon and then describe what you are proactively doing to enhance your skills } \\
\text { in this area. Highlighting an area for improvement demonstrates you are self-aware. Describing } \\
\text { what you are doing about that weakness demonstrates you are proactive and seek to continually } \\
\text { improve your talents. Including asking peers for assistance and consultation shows collegiality. } \\
\text { Common challenging areas in counseling include being overwhelmed, having trouble juggling } \\
\text { responsibilities, burnout, taking client issues home, as well as dilemmas of maintaining good } \\
\text { boundaries while extending caring. }\end{array}$ \\
\hline $\begin{array}{l}\text { Having prepared } \\
\text { questions in response }\end{array}$ & $\begin{array}{l}\text { Every interview usually ends with asking for your questions. Having no questions shows you } \\
\text { are either not interested or not prepared. Go into interviews prepared with intelligent questions. } \\
\text { If you're creative, you can come up with questions that weren’t already covered in the interview. } \\
\text { Most people enjoy talking about themselves, so you usually can’t go wrong by asking the inter- } \\
\text { viewer about his or her personal experience with the organization. Why did he or she choose to } \\
\text { work here? What does he or she like about it? }\end{array}$ \\
\hline
\end{tabular}

